\title{
Daya Tarik Wisata Pura Langgar: \\ Representasi Persaudaraan Hindu-Islam di Bali
}

\author{
Ida Bagus Gde Pujaastawa ${ }^{1}$, I Putu Sudana ${ }^{2}$, \\ Bambang Dharwiyanto Putro \\ 1,2,3 Universitas Udayana \\ Email: guspuja@gmail.com
}

\begin{abstract}
Langgar Temple Tourism Attraction:

Representation of Hindu-Islamic Brotherhood in Bali
\end{abstract}

This article discusses the existence of the Langgar Temple in Bunutin Village, Bangli, as a tourist attraction as well as a representation of interfaith fraternity, especially Hinduism and Islam. Pura Langgar or known as Pura Penataran Agung Dalem Jawa Bunutin, is a complex of places of worship for Hindus in which there are also places of worship for Muslims in the form of langgar buildings. The existence of Langgar Temple is an interesting phenomenon to be studied, because lately began to get tourist visits, especially Muslim tourists. This is a qualitative descriptive study by collecting data through field observation techniques, interviews, literature studies, and document examinations. This study concludes that the existence of Langgar Temple which reflects the history of acculturation between Hindu and Islamic culture is a cultural heritage that is quite potential to attract tourist. The existence of langgar buildings in the temple complex represents the spirit of HinduIslamic brotherhood which is very important in building the spirit of multiculturalism in Indonesia.

Keywords: Pura Langgar, representation, tourism attraction, Hindu, Islam

\footnotetext{
Abstrak

Artikel ini membahas keberadaan Pura Langgar di Desa Bunutin, Bangli, sebagai daya tarik wisata sekaligus representasi persaudaraan antarumat beragama, khususnya Hindu dan Islam. Pura Langgar atau yang dikenal dengan sebutan
} 
Pura Penataran Agung Dalem Jawa Bunutin, merupakan kompleks tempat ibadah umat Hindu yang di dalamnya juga terdapat tempat ibadah umat Islam berupa bangunan langgar. Keberadaan Pura Langgar merupakan fenomena yang menarik untuk dikaji, karena belakangan ini mulai mendapat kunjungan wisatawan, khususnya wisatawan muslim. Kajian ini bersifat deskriptif kualitatif dengan pengumpulan data dilakukan melalui teknik pengamatan lapangan, wawancara, studi kepustakaan, dan pemeriksaan dokumen. Hasil analisis menyimpulkan bahwa keberadaan Pura Langgar yang mencerminkan sejarah akulturasi antara kebudayaan Hindu dan Islam merupakan pusaka budaya yang cukup potensial untuk menarik kunjungan wisatawan. Keberadaan bangunan langgar di dalam kompleks pura merepresentasikan semangat persaudaraan Hindu-Islam yang sangat penting artinya dalam membangun semangat multikulturalisme di Indonesia.

Kata Kunci : Pura Langgar, representasi, daya tarik wisata, Hindu, Islam

\section{Pendahuluan}

Dopularitas Pulau Bali sebagai destinasi pariwisata bertumpu 1 pada kebudayaan Bali yang dijiwai oleh agama Hindu sebagai potensi daya tarik dominan, didukung pula oleh potensi daya tarik wisata alam dan buatan yang cukup beragam. Terkait dengan keberadaan kebudayaan Bali yang dijiwai oleh agama Hindu sebagai daya tarik wisata dominan, maka Pulau Bali juga dikenal dengan julukan "Pulau Dewata" atau "Pulau Seribu Pura" (Wiana, 2004:

1). Di antara ribuan pura yang tersebar di Bali, terdapat sejumlah pura sebagai daya tarik wisata yang tergolong sudah populer baik di kalangan wisatawan nusantara maupun mancanegara, seperti Pura Besakih, Pura Lempuyang, Pura Tanah Lot, Pura Uluwatu, Pura Taman Ayun, Pura Batukaru, dan Pura Kehen.

Selain sejumlah pura di atas, Pura Penataran Agung Dalem Jawa Bunutin yang terletak di Desa Bunutin, Kecamatan Bangli, Kabupaten Bangli, belakangan ini juga mulai menarik minat wisatawan. Hingga sejauh ini tidak tersedia catatan tentang jumlah 
wisatawan yang berkunjung ke Pura Langgar, namun berdasarkan keterangan pihak prajuru (pengurus) pura diperkirakan rata-rata jumlah wisatawan yang berkunjung ke pura ini mencapai 40 orang per bulan. Pura Langgar memiliki keunikan yang berbeda dengan pura di Bali pada umumnya. Di dalam kompleks Pura ini tidak saja terdapat sejumlah palinggih atau bangunan suci bagi umat Hindu, tetapi juga terdapat sebuah bangunan langgar dengan langgam arsitektur tradisional Bali yang berfungsi sebagai tempat ibadah bagi umat Islam. Keberadaan bangunan langgar inilah yang menyebabkan pura ini lebih dikenal dengan sebutan Pura Langgar sebagai nama lain dari Pura Penataran Agung Dalem Jawa Bunutin.

Keberadaan Pura Langgar merupakan fenomena yang menarik untuk dikaji. Artikel ini membahas keberadaan Pura Langgar sebagai daya tarik wisata dan mengkaji aspek fungsional Pura Langgar sebagai representasi dari persaudaraan antarumat beragama, khususnya umat Hindu dan Islam. Hal ini dianggap penting mengingat keberadaan Bangsa Indonesia yang bersifat majemuk membutuhkan upaya-upaya untuk menjaga semangat persatuan dan kesatuan bangsa demi tercapainya hasil-hasil yang optimal dalam pembangunan. Menurut Putra (2017), salah satu langkah kongkrit untuk menjaga toleransi antarumat beragama di Balijuga dibuktikan dengan pembangunan kompleks tempatibadah Puja Mandala di Kawasan Pariwisata Nusa Dua, Bali Selatan. Di dalam kompleks Puja Mandala terdapat tempat ibadah lima agama yang berjejer dari timur ke barat, yakni pura, gereja Protestan, wihara, gereja Katolik, dan masjid. Keberadaan Puja Mandala di samping berfungsi sebagai ikon toleransi antarumat beragama berdasarkan spirit kebhinnekatunggalikaan, juga sekaligus sebagai daya tarik wisata.

Pluralitas Bangsa Indonesia tidak hanya ditandai dengan perbedaan suku-bangsa dan bahasa, tetapi juga agama. Keanekaragaman suku-bangsa, kebudayaan, dan agama yang tersebar di seluruh persada Nusantara di satu sisi merupakan kebanggan sebagaimana tertuang dalam romantisme ungkapan "Nusantara, laksana untaian zamrud di khatulistiwa". Sementara di sisi lain, 
kondisi majemuk bangsa Indonesia juga kerap menjadi kendala bagi upaya pembangunan kesatuan dan persatuan bangsa. Kendala yang dimaksud misalnya ketegangan atau konflik bernuansa SARA (suku, agama, ras, dan antargolongan) dan gerakan-gerakan sparatis yang kerap mengusung simbol-simbol agama seperti yang terjadi di beberapa daerah di Indonesia belakangan ini (Madjid, 2001).

Munculnya ketegangan-ketegangan bernuansa SARA seperti dikemukakan di atas kerap dipengaruhi oleh cara pandang masingmasing pihak dalam menyikapi perbedaan. Oleh karenanya, untuk menjaga dan memupuk rasa kesatuan dan persatuan nasional, diperlukan pengetahuan dan pemahaman yang mendalam dari semua pihak mengenai keberadaan aneka warna suku-bangsa, kebudayaan, dan agama di Indonesia. Langkah tersebut diharapkan mampu menumbuhkembangkan sikap saling pengertian dan saling menghargai satu sama lain dalam wujud solidaritas nasional. Di samping itu, pengetahuan dan pemahaman yang mendalam mengenai keberadaan aneka warna suku-bangsa di Indonesia juga diharapkan mampu menumbuhkembangkan kesadaran dan ketahanan identitas budaya dan jati diri bangsa Indonesia dalam rangka menghadapi proses interaksi antarbudaya yang kian mendunia (Kartodirdjo, 1999).

Menyadari keberadaan Bangsa Indonesia yang bersifat multi etnik, terlebih lagi dengan kian maraknya isu-isu intoleransi bernuansa SARA belakangan ini, maka upaya-upaya untuk menjaga dan memupuk rasa persatuan dan kesatuan bangsa merupakan agenda yang sangat mendesak. Upaya tersebut tidak saja dilakukan melalui pendekatan politik, tetapi juga pendekatan sosial-budaya, khususnya melalui pariwisata. Dalam konteks ini pariwisata diharapkan dapat menjadi wahana untuk menumbuhkembangkan sikap saling pengertian dan saling menghargai dalam wujud solidaritas antarumat beragama. Melalui pariwisata, sikap saling pengertian dan saling menghargai keberagaman tidak saja terbatas di tataran lokal, tetapi juga di tataran nasional, dan internasional (Ismayanti, 2010; Satrya, 2014). 


\section{Metode}

Penelitian ini berlangsung selama tiga bulan, yakni dari 1 Mei sampai dengan 31 Juli 2017, dengan mengambil lokasi di Desa Bunutin, Kecamatan Bangli, Kabupaten Bangli, Provinsi Bali. Penelitian ini menggunakan metode pendekatan deskriptif kualitatif. Pengumpulan data dilakukan dengan menggunakan teknik observasi, wawancara mendalam dan terstruktur, kepustakaan. dan dokumen.

Teknik observasi digunakan untuk memperoleh gambaran tentang kondisi eksisting daya tarik wisata Pura Langgar dan berbagai peristiwa atau aktivitas yang merepresentasikan relasi persaudaraan antarumat agama, khususnya Hindu dan Islam. Observasi dilakukan setiap akhir pekan (Jumat, Sabtu, dan Minggu), dengan asumsi bahwa pada hari-hari tersebut kunjungan wisatawan relatif lebih tinggi daripada hari-hari lainnya.

Teknik wawancara dibedakan atas wawancara mendalam dan wawancara terstruktur. Wawancara mendalam dilakukan guna memperoleh pemahaman tentang sejarah dan pemaknaanpemaknaan yang berkaitan dengan keberadaan daya tarik wisata Pura Langgar. Wawancara mendalam dilakukan terhadap sejumlah informan terpilih, seperti pangelingsir atau sesepuh Puri Agung Bunutin, prajuru desa adat, dan pemerhati sejarah kebudayaan. Wawancara terstruktur digunakan untuk memperoleh pemahaman tentang hal-hal yang berkaitan dengan karakteristik wisatawan yang berkunjung ke daya tarik wisata Pura Langgar yang dilakukan dengan penyebaran kuesioner kepada wisatawan. Penyebaran kuesioner dilakukan setiap akhir pekan (Jumat, Sabtu, dan Minggu), dengan asumsi bahwa pada hari-hari tersebut kunjungan wisatawan relatif lebih tinggi

Teknik kepustakaan digunakan untuk menelaah pustakapustaka terdahulu yang dapat memberi inspirasi sekaligus menjadi referensi bagi kajian ini. Teknik dokumen digunakan untuk memeriksa dokumen-dokumen seperti arsip, foto, dan manuskrip yang diperlukan untuk mendukung kajian ini. 


\title{
3. Kemajemukan dan Multikulturalisme
}

Dalam dinamika pembangunan Bangsa Indonesia, masalah hubungan antaretnik, antarumat beragama mendapat perhatian yang serius dan diakui sebagai aspek yang sering memunculkan masalah SARA. Meskipun berbagai upaya telah dilakukan, namun ketegangan dan perselisihan horizontal bernuansa agama masih kerap mewarnai negeri ini. Berkenaan dengan ini budayawan Nurcholis Madjid menyatakan keprihatinannya :

\begin{abstract}
"akhir-akhir ini kita menyaksikan dengan perasaan mencekam suasana hubungan antarumat beragama di tanah air mulai terusik, bahkan telah menelan banyak korban jiwa, kehormatan dan harta benda. Padahal, bangsa Indonesia sering membanggakan atau dibanggakan sebagai bangsa yang memiliki tingkat toleransi dan kerukunan beragama yang sangat tinggi. Namun, intensitas konflik di masyarakat kita akhir-akhir ini yang diduga telah melibatkan penganut agama-agama dengan tingkat kekejaman yang sulit diterima akal sehat" (Madjid, 2001: 2).
\end{abstract}

Pada tataran global, hal senada juga dinyatakan oleh Huntington (2002) yang memprediksi masa depan politik dunia diwarnai oleh benturan antarperadaban yang tidak lepas dari simbol-simbol agama. Salah satu alternatif solusi untuk mengatasi merebaknya benturan antarperadaban adalah melalui gerakan multikultural yang dilandasi semangat saling menghargai perbedaan (multikulturalisme).

Pengertian multikulturalisme memiliki dua ciri utama, yaitu (1) kebutuhan terhadap pengakuan (the need of recognition), dan (2) legitimasi keragaman budaya atau pluralisme budaya (Tilaar, 2004: 83). Lawrence Blum (2001: 16), mengajukan definisi mengenai multikulturalisme sebagai sebuah pemahaman, penghargaan, dan penilaian atas budaya seseorang, dan sebuah penghormatan dan keingintahuan tentang budaya etnis orang lain. Ia meliputi sebuah penilaian terhadap kebudayaan-kebudayaan orang lain, bukan dalam arti menyetujui seluruh aspek dari kebudayaan-kebudayaan tersebut, melainkan mencoba melihat bagaimana kebudayaan tertentu dapat mengekspresikan nilai bagi anggota-anggotanya sendiri". 
Dalam tataran teoritik, multikulturalisme merupakan varian dari teori perbedaan yang diilhami gagasan posmodernisme yang menyatakan bahwa perbedaan manusia secara analitis lebih penting daripada kesamaan mereka. Paradigma multikulturalisme merayakan perbedaan sebagai suatu kerangka kerja yang ada di dalamnya untuk mengahargai banyak kelompok dan narasi khas mereka masing-masing. Terlebih lagi multikulturalisme posmodern menentang kemungkinan menyatunya kelompok-kelompok yang berbeda ke dalam satu alasan bersama yang dapat mengubah struktur sosial secara totalitas (Agger, 2003: 140).

Di Indonesia, meskipun model multikultural sesungguhnya telah dijadikan acuan oleh para pendiri bangsa dalam mendesain Bangsa Indonesia yang Bhinneka Tunggal Ika, namun wacana mengenai masyarakat multikultural mulai merebak sebagai agenda Reformasi 1998. Salah satu agenda penting dari cita-cita reformasi adalah mambangun tatanan masyarakat Indonesia Baru yang bersifat multikultural, yakni menegakkan kehidupan bersama yang demokratis, mengakui hak dan martabat manusia yang sama (human dignity), menghormati perbedaan-perbedaan kebudayaan masyarakat Indonesia yang bersifat majemuk, dan bertekad untuk membangun kesatuan Indonesia dalam wadah Negara Kesatuan Republik Indonesia sebagai perwujudan Sumpah Pemuda tahun 1928 (Tilaar, 2004: 192).

Acuan utama bagi terwujudnya masyarakat yang multikultural adalah multikulturalisme, yaitu sebuah ideologi yang mengakui dan mengagungkan perbedaan dalam kesederajatan, baik secara individual maupun secara kebudayaan (Fay 1996; Jary dan Jary 1991; Watson 2000; Kymlicka 2002). Dalam model multikulturalisme ini, sebuah masyarakat (termasuk juga masyarakat bangsa seperti Indonesia) dilihat mempunyai sebuah kebudayaan yang berlaku umum dalam masyarakat tersebut yang coraknya seperti sebuah mosaik. Di dalam mosaik tercakup semua kebudayaan dari masyarakat-masyarakat lebih kecil yang membentuk terwujudnya masyarakat yang lebih besar, yang mempunyai kebudayaan seperti sebuah mozaik tersebut (Reed 1997). 


\section{Pariwisata sebagai Wahana Perdamaian}

Di tataran global, fenomena keanekaragaman budaya mulai mendapat perhatian serius pada pergantian abad ini. Hal ini terkait dengan proses globalisasi yang berimplikasi terhadap gesekan antarbudaya yang menyebabkan meningkatnya berbagai ketegangan yang bernuansa politik identitas, khususnya masalah agama yang dapat menjadi sumber perdebatan potensial. Oleh sebab itu, perlu dibangun paradigma baru tentang keanekaragaman budaya sebagai sesuatu hal yang positif yang bertujuan untuk saling berbagi kekayaan budaya yang dapat mempersatukan masyarakat dunia melalui berbagai proses pertukaran dan dialog lintas budaya (UNESCO, 2011).

Pariwisata sejatinya merupakan fenomena perjumpaan kebudayaan di mana keanekaragaman budaya dipahami sebagai suatu proses dinamis. Cara terbaik mengelola pertukaran budaya adalah melalui dialog antarbudaya sehingga dapat menjadi pendorong yang kuat untuk memperbarui berbagai strategi masyarakat internasional menuju pembangunan dan perdamaian, berdasarkan pada penghormatan terhadap hak-hak asasi manusia yang diakui secara universal (UNESCO, 2011).

Di Negara Indonesia, peran pariwisata sebagai wahana perdamaian juga mendapat perhatian serius sebagaimana tertuang dalam Undang-undang Republik Indonesia Nomor 10 Tahun 2009 tentang Kepariwisataan. Dalam undang-undang tersebut secara tegas dinyatakan bahwa salah satu tujuan kepariwisataan adalah untuk mempererat persahabatan antarbangsa. Sedangkan prinsip penyelenggaraan kepariwisataan antara lain menjunjung tinggi hak asasi manusia, keragaman budaya dan kearifan lokal, serta memperkukuh keutuhan Negara Kesatuan Republik Indonesia.

\section{Potensi Daya Tarik}

Pura Langgar merupakan sebuah pusaka budaya yang dikembangkan sebagai daya tarik wisata sejarah dan religi dengan potensi daya tarik utama berupa sejarah keberadaan Pura Langgar dan kompleks bangunan suci Hindu-Islam. 


\subsection{Sejarah Keberadaan Pura Langgar}

Salah satu potensi yang mendukung Pura Langgar sebagai daya tarik wisata adalah keunikan sejarahnya. Menurut Widyarshana (2008), keberadaan Pura Langgar berawal dari perselisihan antara Raja Dalem Waturenggong yang beristana di Gelgel, Bali, dan Raja Dalem Sri Juru yang beristana di Blambangan, Jawa Timur, pada pertengahan abad XVI. Perselesihan tersebut disebabkan oleh penolakan Raja Blambangan terhadap permohonan Dalem Waturenggong mempersunting putrinya yang bernama Ayu Mas. Akibat penolakan tersebut, Dalem Waturenggong kemudian mengutus Patih Ularan untuk menyerang Kerajaan Blambangan. Dalam penyerangan tersebut Dalem Sri Juru wafat. Tahta Kerajaan Blambangan kemudian diteruskan oleh keturunannya yang bernama Pangeran Mas Sepuh dan saudara tirinya yang bernama Pangeran Mas Wilis atau Wong Agung Wilis sebagai Patih Agung.

Suatu ketika kedua keturunan Raja Blambangan tersebut berniat menghadap Raja Gelgel untuk bersilaturahmi sekaligus memohon maaf atas kelancangan orang tua mereka yang telah menolak lamaran Sang Raja untuk mempersunting Ayu Mas. Setelah menghadap Raja Gelgel, kedua bersaudara ini berniat kembali ke Blambangan. Namun, sebelum menyeberang, mereka diserang oleh sekelompok orang bersenjata yang mengakibatkan Pangeran Mas Sepuh wafat. Sementara itu, Pangeran Wilis berhasil menyelamatkan diri dan mohon perlindungan kepada Raja Gelgel. Oleh Raja Gelgel, Pangeran Wilis diizinkan tinggal di Desa Bunutin dan membangun tempat kediaman yang dikenal dengan sebutan Puri Agung Bunutin dan kompleks bangunan suci yang disebut Pamerajan Agung Bunutin. Di samping itu, Pangeran Wilis juga dinobatkan sebagai penguasa wilayah Bunutin dengan gelar I Dewa Mas Wilis.

Di tengah masa kekuasaannya, I Dewa Mas Wilis wafat meninggalkan dua orang istri dan lima orang putra. Salah satu istrinya adalah keturunan Raja Mengwi yang melahirkan dua orang putra, yaitu Ida I Dewa Mas Blambangan dan Ida I Dewa Mas Bunutin. Sepeninggal I Dewa Mas Wilis, tahta kekuasaan 
diwarisi putra sulungnya, yaitu I Dewa Mas Blambangan. Belum lama bertahta, tiba-tiba I Dewa Mas Blambangan menderita sakit yang sulit terobati. Akhirnya pihak keluarga melaksanakan ritual memohon kesembuhan kepada leluhur. Di tengah pelaksanaan ritual itu salah seorang dari mereka mengalami kesurupan dan meminta agar dibuatkan sebuah bangunan yang menyerupai langgar. Permintaan tersebut diyakini berasal dari para leluhur mereka di Tanah Blambangan yang menganut agama Islam. Setelah itu oleh I Dewa Mas Bunutin dibangun sebuah langgar di dalam areal pamerajan puri. Tidak lama berselang, penyakit yang diderita I Dewa Mas Blambangan berangsur-angsur sembuh. Keberadaan langgar inilah yang menyebabkan Pamerajan Agung Dalem Jawa Bunutin kemudian dikenal dengan nama Pura Langgar.

\subsection{Kompleks Bangunan Suci Hindu dan Islam}

Keberadaan Pura Langgar menjadi unik dan menarik, karena di dalam kompleks pura tersebut terdapat sebuah arsitektur bangunan suci berbentuk persegi empat dengan luas lantai berukuran 5x5 meter yang menyerupai musholla atau langgar, tempat ibadah umat muslim (Foto 1). Keberadaan bangunan suci ini tergolong building attraction yang di samping mengandung nilainilai estetika, juga nilai-nilai historis yang mencerminkan proses akulturasi peradaban Hindu dan Islam pada masa lampau.

Berbeda dengan bentuk arsitektur bangunan tempat suci (pura) di Bali pada umumnya, arsitektur bangunan Pura Langgar menyerupai sebuah langgar berundak dua, berpintu empat, serta atapnya bertingkat dua. Konon, dua tingkat atap tersebut melambangkan syariat atau hukum yang mengatur tata kehidupan dan peribadatan umat muslim, sedangkan dua undak melambangkan jalan menuju Tuhan. Bangunan yang penuh ukiran ini memiliki pintu di setiap sisinya, yang mencirikan tempat persembahyangan umat Islam. Pura ini dilengkapi pula dengan beberapa fasilitas seperti tempat berwudhu dan sholat bagi umat Islam, dan toilet. Areal pura dikelilingi oleh telaga yang dihiasi bunga teratai. Di sekitarnya juga terdapat beberapa pura lainnya 


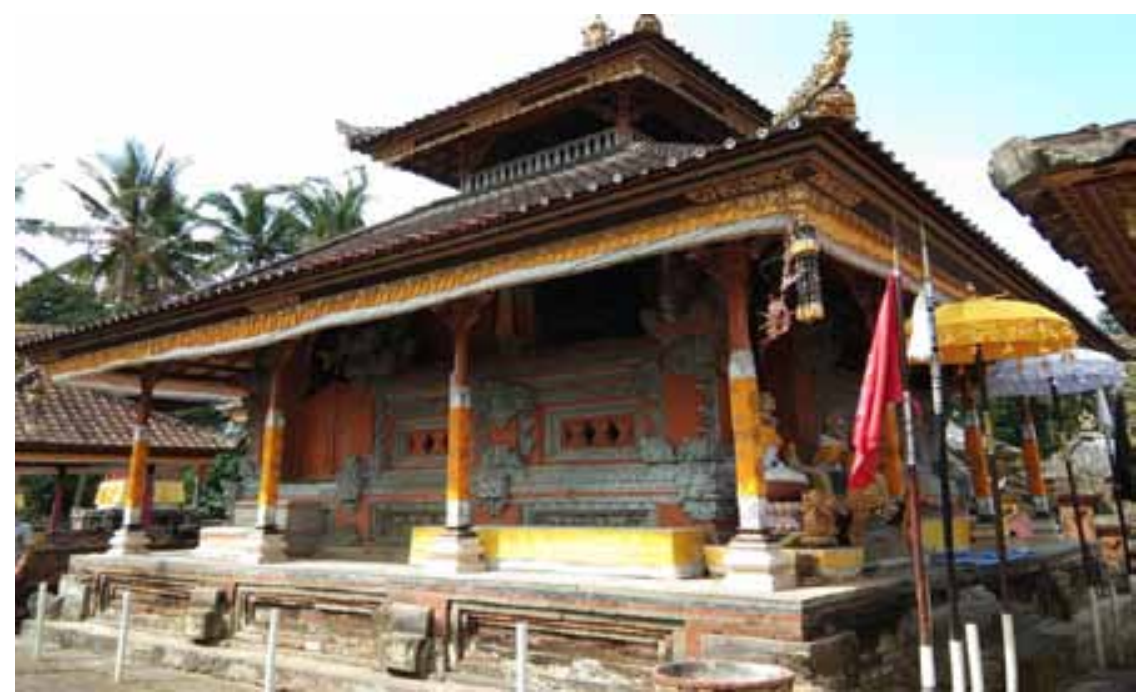

Foto 1. Bangunan Langgar dengan Langgam Arsitektur Tradisional Bali (Foto: Pujaastawa).

seperti Pura Penataran Agung Bunutin, Pura Pajenengan, dan Pura Dalem Desa Adat Bunutin.

\section{Representasi Persaudaraan Hindu-Islam}

Keunikan Pura Langgar di samping sebagai potensi daya tarik wisata juga merupakan pusaka budaya yang merepresentasikan semangat persaudaraan antarumat beragama, khususnya HinduIslam pada masa lampau yang masih terpelihara hingga sekarang. Representasi semangat persaudaraan Hindu-Islam tersebut dapat dijelaskan sebagai berikut.

\subsection{Keberadaan Langgar di dalam Kompleks Pura}

Keberadaan bangunan langgar di dalam kompleks Pura Penataran Agung Dalem Jawa Bunutin mengindikasikan adanya proses penetration pacifique, yakni masuknya unsur-unsur kebudayaan luar secara damai pada masa lampau. Fenomena ini dimungkinkan oleh adanya rasa saling berterima antara kelompok penganut agama yang berbeda, khususnya antara pihak keluarga Puri Agung Bunutin yang menganut agama Hindu dan keluarga 
Raja Blambangan yang menganut agama Islam. Dalam hal ini pihak keluarga Puri Agung Bunutin dapat menerima kehadiran simbolsimbol agama Islam di dalam lingkungan tempat suci (pura) mereka. Demikian pula pihak keluarga Raja Blambangan tidak berkeberatan terhadap keberadaan langgar yang dibangun di dalam kompleks tempat suci agama Hindu. Terlebih lagi keberadaan bangunan langgar di dalam kompleks Pura Penataran Agung Dalem Jawa Bunutin dilegitimasi pula oleh adanya keyakinan bahwa fenomena tersebut, atas kehendak leluhur sebagaimana telah diuraikan dalam sejarah keberadaan Pura Langgar (lihat uraian pada butir 4.1).

Sikap saling berterima antarkelompok penganut agama yang berbeda ini merupakan bentuk solidaritas yang dipengaruhi oleh faktor hubungan geneologis dalam sistem kekerabatan di mana kedua kelompok kerabat yang berbeda keyakinan sama-sama merasa berasal dari leluhur yang sama. Terpeliharanya solidaritas berdasarkan ikatan genealogis sangat efektif dalam meredam berbagai potensi konflik termasuk konflik yag bersumber pada perbedaan keyakinan. Bentuk solidaritas sosial semacam itu antara lain juga ditemukan pada masyarakat Batak Karo yang terpolarisasi ke dalam beberapa kelompok penganut agama yang berbeda, seperti Kristen Protestan, Katholik, Islam, Budha, dan Hindu. Meskipun terpolarisasi ke dalam beberapa kelompok penganut agama yang berbeda, namun mereka tetap terintegrasi dalam ikatan solidaritas kekerabatan yang disebut daliken si telu (Lubis, 2017; Brahmana, 2003). Fenomena serupa juga dapat dijumpai dalam kehidupan masyarakat Kampung Sawah, Bekasi yang terpolarisasi ke dalam beberapa kelompok agama (Islam, Katholik, dan Protestan). Namun kohesivitas antarkelompok agama relatif tinggi karena mereka merasa berasal dari pu'un atau leluhur yang sama (Jamaludin, 2018).

Berdasarkan catatan sejarah, penetrasi secara damai unsurunsur kebudayaan luar dalam kehidupan masyarakat Bali sejatinya telah berlangsung sekitar abad ke-9 yang ditandai dengan datangnya pengaruh agama Khonghucu melalui kontak perdagangan dengan orang-orang China (Miksic, 1996). Selanjutnya tonggak kedatangan 
pengaruh agama Islam ke Bali dimulai sekitar abad ke-15, ditandai dengan kedatangan sejumlah utusan Raden Fatah dari Kerajaan Demak untuk memperkenalkan agama Islam kepada Raja Dalem Waturenggong yang beristana di Gelgel, Klungkung (Reken, 1979: 7). Sementara kehadiran pengaruh agama Kristen ke Bali dimulai sejak awal abad ke-20 yang ditandai dengan pembaptisan sejumlah orang Bali menjadi pemeluk agama Kristen (Mastra, dalam Pujaastawa, 2009).

Kehadiran kelompok-kelompok pendatang dengan identitas kultural yang berbeda tersebut sangat dihargai oleh masyarakat Bali antara lain dengan memberikan kebebasan kepada mereka untuk menjalankan tradisi keagamaan sesuai dengan keyakinan yang dianutnya. Hal ini dapat dibuktikan dengan keberadaan tempat-tempat ibadah umat Konghucu, Islam, dan Kristen di lingkungan perkampungan orang Bali. Bahkan di beberapa tempat seperti di Desa Batur (Bangli), Pesanggaran (Denpasar), Abiansemal (Badung), tempat ibadah umat agama lain juga dibangun di dalam kompleks pura yang merupakan tempat ibadah umat Hindu (Pujaastawa, 2009).

Fenomena di atas mengindikasikan bahwa semangat menghargai perbedaan yang menyangkut hubungan antarsuku, agama, dan ras di kalangan masyarakat Bali sejatinya telah terbangun sejak lama. Kedatangan kelompok-kelompok masyarakat dengan identitas kultural yang berbeda disikapi dengan semangat toleransi dan penghargaan yang tinggi terhadap hak-hak kultural mereka. Adanya sikap menghargai kelompok yang berbeda di kalangan masyarakat Bali tidak terlepas dari nilai-nilai agama Hindu yang dianut oleh sebagian besar penduduknya. Agama Hindu antara lain mengajarkan bahwa tujuan hidup manusia adalah untuk mencapai kesejahteraan lahir dan bathin atau moksartham jagadhita. Dalam rangka mencapai kesejahteraan lahir dan bathin dikenal konsep Tri Hita Karana atau tiga penyebab kesejahteraan, yakni hubungan yang harmonis antara antara manusia dengan lingkungan yang beragam, yang terdiri dari lingkungan spiritual (parhyangan), lingkungan sosial (pawongan), dan lingkungan fisik (palemahan). Hubungan yang harmonis antara manusia dan ketiga ragam lingkungan 
tersebut diyakini akan membawa manfaat bagi kesejahteraan hidup lahir dan bathin, sebaliknya, hubungan yang tidak harmonis diyakini akan mengancam kesejahteraan hidup mausia. Dengan demikian, semangat menghargai keberagaman bagi masyarakat Bali sesungguhnya tidak hanya terbatas dalam konteks hubungan antara manusia dan lingkungan sosial semata, tetapi juga lingkungan spiritual dan lingkungan fisik (Pujaastawa, 2009).

Ajaran Hindu lainnya yang juga dijadikan acuan demi terciptanya hubungan yang harmonis antara manusia dan lingkungan sosialnya adalah tatwam asi yang berarti "engkau adalah dia" atau "aku adalah engkau". Faham ini mengandung prinsip-prinsip solidaritas, toleransi, kesetaraan, perdamaian, dan keadilan sosial antarsesama umat manusia. Berdasarkan ajaran ini segala bentuk dominasi dan penindasan manusia terhadap manusia lainnya tidaklah dibenarkan (Pujaastawa, 2009). Sebagaimana pula dinyatakan Swasono (2003), bahwa manusia sebagai homo economicus yang mengidap akhlak egoisme, perlu memahami hakikat manusia sebagai homo socius ataupun homo tatwam asi. Dengan demikian, dalam meperjuangkan kepentingannya, manusia hendaklah juga menghormati kepentingan manusia lain.

\subsection{Sebutan "Pura Langgar"}

Sebutan "Pura Langgar" merupakan sebutan lain dari Pura Penataran Agung Dalem Jawa Bunutin. Keberadaan bangunan langgar di dalam kompleks Pura Penataran Agung Dalem Jawa Bunutin menyebabkan pura ini lebih dikenal dengan sebutan "Pura Langgar". Sebutan "Pura Langgar" semakin terlegitimasi oleh papan nama pura yang dipasang di pinggir jalan raya, di mana tulisan "Pura Langgar" dibuat lebih menonjol dengan huruf kapital yang berukuran lebih besar daripada tulisan "Penataran Agung Bunutin".

Sebutan "Pura Langgar" mengekspresikan adanya pengakuan umat Hindu terhadap eksistensi agama atau sistem keyakinan yang berbeda, yaitu Islam. Adanya pengakuan terhadap eksistensi agama yang berbeda dapat menghindarkan kelompok penganut agama dari kesan eksklusivisme, yakni sikap menutup diri terhadap relasi 
sosial dengan penganut agama lain. Eksklusivisme agama dilandasi oleh adanya pandangan penganut agama tentang ajaran agamanya yang paling benar, sementara ajaran agama lain dianggap salah dan sesat. Oleh karena itu eksklusivisme sangat berpotensi melahirkan radikalisme yang kerap menimbulkan keresahan dan kegelisahan dalam konteks membangun kehidupan beragama yang damai dan toleran (Bakar, 2016).

Terkait dengan eksklusivisme agama, Fadl (2006) menggunakan istilah "puritan" yang juga mengandung makna senada dengan istilah fundamentalis, militan, ekstrimis, radikal, fanatik, jahidis dan ekstrimis. Menurutnnya, kelompok ini memiliki karakter intoleran, bercorak reduksionisme, fanatik, literalisme, dan memandang realitas pluralis sebagai bentuk kontaminasi atas kebenaran sejati. Sebaliknya, insklusivisme adalah sikap keagamaan yang berpandangan bahwa di luar agama yang dipeluknya juga terdapat kebenaran. Kelompok inklusif biasanya cenderung mendorong pemeluknya bersikap terbuka terhadap kelompok dari agama lain. Sikap terbuka akan membuka peluang bagi terciptanya relasi sosial yang sehat dan harmonis yang mendukung terciptanya kerukunan antarumat beragama (Bakar, 2016) (Foto 2).

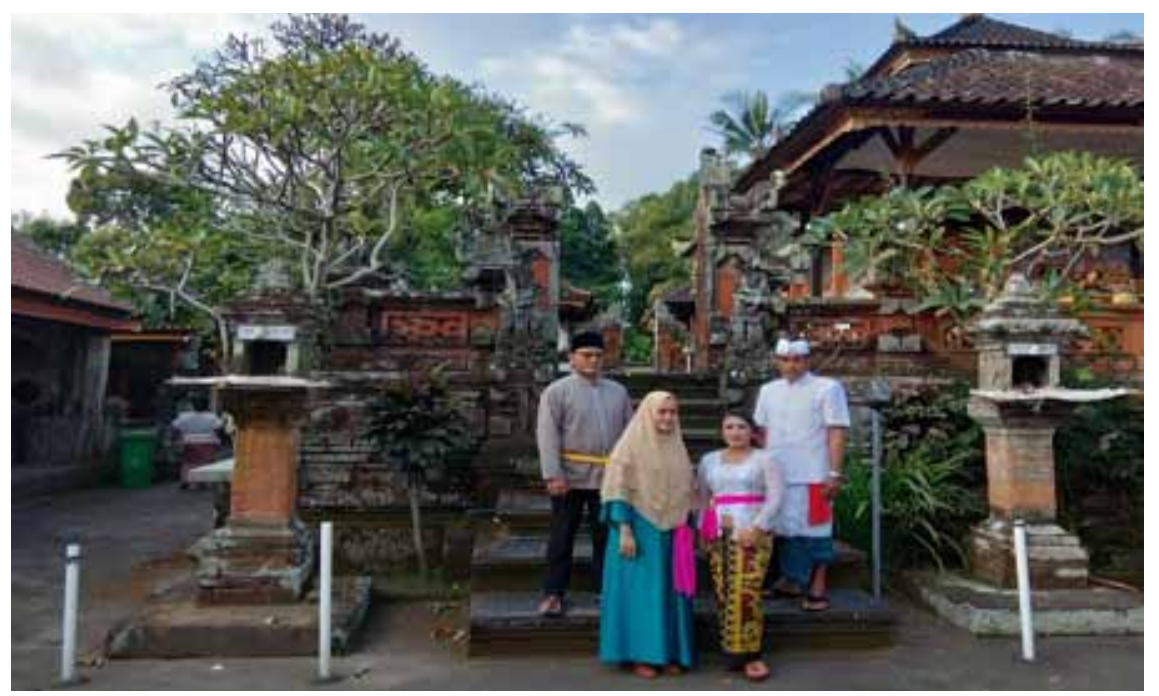

Foto 2. Pura Langgar sebagai wahana persaudaraan (Foto: Pujaastawa) 


\subsection{Ibadah Sholat di Lingkungan Pura}

Salah satu indikator penting tentang toleransi antarumat beragama adalah adanya sikap saling menghormati atau sikap tidak berkeberatan dari kelompok penganut agama tertentu terhadap pelaksanaan kegiatan keagamaan yang dilakukan oleh kelompok penganut agama lain di lingkungan tempat tinggalnya (Hermawati, dkk., 2016).

Berdasarkan agama yang dianut, wisatawan yang melakukan kunjungan ke Pura Langgar dapat digolongkan seperti pada tabel berikut.

Tabel 1. Wisatawan yang Mengunjungi Pura Langgar Digolongkan Berdasarkan Agama

\begin{tabular}{clccc}
\hline No. & & Agama & Jumlah & $(\%)$ \\
\hline 1. & Islam & 95 & 95 \\
2. & Hindu & 5 & 5 \\
3. & Lainnya & - & - \\
\hline \multicolumn{2}{r}{} & Total & 100 & 100 \\
\hline
\end{tabular}

Sumber : Survei Lapangan

Tabel 1 menunjukkan bahwa wisatawan yang melakukan kunjungan ke daya tarik wisata Pura Langgar didominasi oleh kelompok wisatawan beragama Islam atau wisatawan muslim yang mencapai 95\%. Jumlah ini jauh melebihi kelompok wisatawan yang beragama Hindu yang hanya mencapai angka 5\%.

Tingginya angka wisatawan muslim yang berkunjung ke daya tarik wisata Pura Langgar mengindikasikan tingginya minat mereka untuk mengetahui keberadaan daya tarik tersebut. Selain untuk tujuan berekreasi, sebagian dari wisatawan muslim yang berkunjung ke Pura Langgar juga termotivasi untuk melaksanakan kegiatan peribadatan, khususnya ibadah sholat. Berikut tabel penggolongan wisatawan muslim yang berkunjung ke Pura Langgar berdasarkan jenis motivasi kunjungannya. 
Tabel 2. Wisatawan yang Mengunjungi Pura Langgar Digologkan Berdasarkan Motivasi Kunjungan

\begin{tabular}{rlcc}
\hline No. & \multicolumn{1}{c}{ Motivasi Kunjungan } & Jumlah & (\%) \\
\hline 1. & Rekreasi & 38 & 40 \\
2. & Ibadah & - & - \\
3. & Rekreasi dan ibadah & 57 & 60 \\
\hline & Total & 95 & 100 \\
\hline
\end{tabular}

Sumber : Survei Lapangan

Tabel 2 menunjukkan bahwa lebih dari separoh (60\%) wisatawan yang melakukan kunjungan ke daya tarik wisata Pura Langgar dimotivasi oleh keinginan untuk berekreasi dan ibadah, sementara yang lainnya (40\%) sepenuhnya dimotivasi oleh keinginan untuk berekreasi. Jenis-jenis kegiatan rekreasi yang dilakukan wisatawan di lingkungan daya tarik wisata Pura Langgar umumnya adalah melihat-lihat keunikan arsitektur Pura Langgar dan mendengar penjelasan tentang latar belakang sejarah keberadaan Pura Langgar.

Untuk mengakomodasi kepentingan wisatawan yang ingin menunaikan ibadah sholat, pihak pengelola Pura Langgar juga menyediakan perlengkapan seperti karpet lantai dan tempat berwudhu. Kenyataan ini menunjukkan adanya sikap toleransi yang tinggi dari keluarga Puri Agung Bunutin terhadap penganut agama lain (Islam) untuk melaksanakan ibadahnya. Seperti dinyatakan Mursyid (2016), bahwa sikap toleransi antarumat beragama antara lain dapat berupa pemberian ruang gerak yang luas bagi pemeluk agama untuk memeluk agamanya masing-masing termasuk menjunjung tinggi hak orang lain untuk dapat beribadah sesuai dengan keyakinan yang dimilikinya.

Demikian pula bagi kalangan wisatawan muslim yang dapat menerima keberadaan langgar di dalam kompleks pura dan hal tersebut tidak menghalangi niat mereka untuk menunaikan ibadah. Dengan demikian, masing-masing pemeluk agama dapat menjalankan ritual agamanya dengan rasa kedamaian, sehingga 
akan mencipta suasana kerukunan hidup antarumat beragama yang harmonis.

\subsection{Kunjungan Ulang}

Di antara wisatawan muslim yang berkunjung ke Pura Langgar, sebagian di antaranya memiliki loyalitas terhadap Pura Langgar yang dibuktikan dengan keinginannya untuk melakukan kunjungan ulang atau repeater. Keinginan untuk melakukan kunjungan ulang dipengaruhi oleh tingkat kepuasan wisatawan terhadap daya tarik wisata yang dikunjungi (Kozak, 2000). Berikut adalah tabel penggolongan wisatawan yang mengunjungi Pura Langgar berdasarkan keinginannya untuk melakukan kunjungan ulang.

Tabel 3. Wisatawan yang Mengunjungi Pura Langgar Digolongkan Berdasarkan Niat untuk Melakukan Kunjungan Ulang.

\begin{tabular}{|c|c|c|c|}
\hline No. & Niat Kunjungan Ulang & Jumlah & $(\%)$ \\
\hline 1. & Ya & 78 & 78 \\
\hline 2. & Ragu-ragu & 14 & 14 \\
\hline 3. & Tidak & 8 & 8 \\
\hline & Total & 100 & 100 \\
\hline
\end{tabular}

Sumber : Survei Lapangan

Data dalam tabel 3 menunjukkan bahwa sebagian besar (78\%) wisatawan yang mengunjungi Pura Langgar menyatakan keinginannya untuk melakukan kunjungan ulang, sedangkan wisatawan yang menyatakan ragu-ragu sebanyak 14\%, dan wisatawan yang menyatakan tidak berniat untuk melakukan kunjungan ulang berjumlah $8 \%$. Tingginya minat wisatawan muslim untuk melakukan kunjungan ulang ke daya tarik wisata Pura Langgar mengindikasikan tingginya loyalitas mereka terhadap daya tarik tersebut.

Merujuk Griffin (2003), salah satu faktor yang mempengaruhi loyalitas wisatawan adalah adanya ikatan emosional dari wisatawan terhadap daya tarik wisata yang dikunjunginya. 
Loyalitas wisatawan muslim terhadap daya tarik wisata Pura Langgar tidak terlepas dari nilai-nilai historis dan religius yang mampu menumbuhkan kesadaran akan adanya ikatan persaudaraan antarkelompok penganut agama yang berbeda. Loyalitas tersebut merupakan modal sosial yang sangat penting artinya dalam menjaga kerukunan antarumat beragama. Dalam konteks pengembangan pariwisata, terbangunnya loyalitas yang dilandasi oleh rasa toleransi dan persaudaraan merupakan modal yang sangat berharga bagi pengembangan wisata damai di Pulau Dewata. Seperti dinyatakan Ariana (2017), bahwa pariwisata damai atau peace tourism adalah pariwisata yang berbasiskan nilai-nilai luhur budaya yang humanis, nilai kebersamaan, solidaritas, tanpa kekerasan, keadilan, saling menghormati/menghargai, spritualitas, dan keharmonisan. Lebih jauh dikemukakan bahwa dalam rangka pengembangan wisata damai perlu dilakukan upaya-upaya antara lain membangun relasi harmonis dengan menumbuhkan rasa solidaritas dan saling pengertian antara wisatawan dan masyarakat lokal.

Loyalitas wisatawan yang dilandasi oleh ikatan sejarah dan religius juga tercermin dari daerah asalnya. Berikut tabel penggolongan wisatawan berdasarkan daerah asalnya.

Tabel 4. Wisatawan yang Mengunjungi Pura Langgar Berdasarkan Daerah Asal

\begin{tabular}{clcc}
\hline No. & \multicolumn{1}{c}{ Daerah Asal (Provinsi) } & Jumlah & $(\%)$ \\
\hline 1. & Jawa Timur & 60 & 60 \\
2. & Jawa Tengah & 24 & 24 \\
3. & Daerah Istimewa Jogjakarta & 8 & 8 \\
4. & Bali & 6 & 6 \\
5. & Lainnya & 2 & 2 \\
\hline & & 100 & 100 \\
\hline
\end{tabular}

Sumber : Survei Lapangan 
Tabel 4 menunjukkan bahwa berdasarkan daerah asalnya, wisatawan yang mengunjungi Pura Langgar didominasi oleh wisatawan yang berasal dari beberapa provinsi di Pulau Jawa, yakni Jawa Timur (60\%), menyusul kemudian Jawa Tengah (24\%), Provinsi DI Yogyakarta (8\%). Sedangkan jumlah wisatawan lokal atau yang berasal dari Provinsi Bali hanya sebesar 6\%, dan provinsi lainnya sebesar $2 \%$.

Tingginya minat wisatawan yang berasal dari Provinsi Jawa Timur untuk berkunjung ke Pura Langgar tidak terlepas dari adanya ikatan historis antara Kerajaan Blambangan (Jawa Timur) dan kerajaan-kerajaan di Bali seperti Kerajaan Mengwi dan Gelgel pada masa lampau. Di samping itu, juga didorong oleh loyalitas berdasarkan sentimen keagamaan yang pada gilirannya mendorong terciptanya kesadaran kolektif di antara mereka untuk melakukan kunjungan ke daya tarik wisata Pura Langgar dalam bentuk kemasan wisata religi.

\subsection{Ritual "Titi Mamah" dan Pantangan Daging Babi}

Setiap tahun sekali, sebulan menjelang hari Raya Nyepi, tepatnya pada hari Tilem Sasih Kawulu atau bulan mati pada bulan ke delapan menurut perhitungan kalender tradisional Bali (sekitar bulan Februari kalender Masehi), di Pura Langgar diselenggarakan ritual Titi Mamah. Dalam prosesi ritual ini seekor godel bang atau anak sapi berbulu merah disembelih dan kepalanya dikurbankan sebagai pakelem atau kurban yang dilarung ke dasar kolam yang mengelilingi Pura Langgar, sementara dagingnya dibagi-bagikan kepada warga. Menurut konsepsi keyakinan masyarakat Bali (Hindu) pada umumnya, fungsi kurban pakelem adalah untuk menetralisir pengaruh kekuatan-kekuatan negatif yang dapat mengganggu keseimbangan antara bhuana agung (macrocosmos) dan bhuana alit (microcosmos) dengan segala isinya (Sutika, 2012).

Ritual Titi Mamah ini selain dihadiri oleh keluarga besar Puri Agung Bunutin dan warga masyarakat sekitarnya, juga dihadiri pula oleh umat muslim yang dengan sengaja ingin menyaksikan 
pelaksanaan ritual tersebut. Ritual ini mengingatkan akan upacara Idul Qurban pada umat muslim yang mengandung makna simbolik antara lain ketaqwaan hamba kepada Tuhannya yang dilandasi oleh rasa tulus ikhlas dan kepedulian sosial antarsesama manusia yang diejawantahkan melalui praktik ritual (asmaul-husna.com). Tidak jauh berbeda dinyatakan Hasan (2014) bahwa makna berkurban antara lain adalah untuk mendekatkan diri kepada Allah Sang Pencipta melalui persembahan yang sangat berharga dan berbagi kepada sesama umat yang kurang mampu.

Hal lain yang mencerminkan terbangunnya semangat saling menghargai perbedaan dapat dilihat dari persembahan sesajen dalam setiap pelaksanaan ritual di Pura Langgar yang pantang menggunakan bahan-bahan yang mengandung unsur babi. Di samping itu, sikap menghargai perbedaan yang ditunjukkan oleh orang Bali Hindu terhadap pemeluk agama Islam di antaranya adalah adanya jenis makanan yang disebut lawar selam yang berarti lawar Islam. Lawar merupakan salah satu jenis makanan khas tradisional yang sangat populer di kalangan masyarakat Bali Hindu. Jenis makanan ini terbuat dari daging dan darah babi yang biasanya dihidangkan dalam rangka pesta adat dan upacara keagamaan di kalangan umat Hindu di Bali. Sedangkan lawar selam tidak terbuat dari daging babi melainkan dari daging hewan lainnya, seperti sapi, ayam, dan itik. Lawar selam ini biasanya dihidangkan kepada kaum muslim atau mereka yang berpantang mengkonsumsi daging babi (Pujaastawa, 2008).

\section{Simpulan}

Secara historis, keberadaan Pura Langgar merupakan salah satu bukti sejarah yang menunjukkan adanya relasi yang harmonis antaragama khususnya Hindu dan Islam pada masa lampau. Sejalan dengan perkembangan pariwisata di Bali, keberadaan Pura Langgar di samping dapat difungsikan sebagai daya tarik wisata, juga menjadi lambang kerukunan antarumat beragama, khususnya Hindu dan Islam. Hal ini menjadi penting dalam rangka 
meningkatkan peran pariwisata dalam memelihara persatuan dan kesatuan bangsa dan perdamaian dunia.

Keberadaan daya tarik wisata Pura Langgar di Desa Bunutin dapat diacu sebagai model wisata damai yang belakangan ini mulai mendapat apresiasi sejalan dengan kian meningkatnya potensi ketegangan yang bersumber pada masalah perbedaan suku, agama, ras, dan golongan. Keberadaan daya tarik wisata Pura Langgar seakan-akan telah mengajarkan kepada kita semua tentang bagaima semestinya mengelola perbedaan dalam persatuan. Perbedaan bukanlah dipandang sebagai musibah yang harus dihindari, melainkan berkah yang harus dijaga dan dihormati. Dengan demikian, semangat saling menjaga dan menghargai perbedaan niscaya akan berbuah kesejahteraan dan kedamaian. Sebaliknya, sikap tidak menghargai perbedaan hanyalah akan melahirkan eksklusivisme dan puritanisme yang pada gilirannya akan berbuah konflik dan kesengsaraan.

Terlebih lagi bagi bangsa Indonesia yang bersifat majemuk, semangat saling menghargai perbedaan haruslah diupayakan secara terus-menerus. Sebagaimana salah satu agenda penting dari citacita reformasi adalah mambangun tatanan masyarakat Indonesia Baru yang bersifat multikultural, yakni menegakkan kehidupan bersama yang demokratis, mengakui kesamaan hak dan martabat manusia (human dignity), menghormati perbedaan kebudayaan masyarakat Indonesia yang bersifat majemuk, dan bertekad untuk membangun kesatuan Indonesia dalam wadah Negara Kesatuan Republik Indonesia yang Bhinneka Tunggal Ika.

\section{Ucapan Terimakasih}

Dengan segala kerendahan hati kami menyampaikan ucapan terimakasih yang sebesar-besarnya kepada Direktorat Riset dan Penelitian Masyarakat Direktorat Jenderal Penguatan Riset dan Pengembangan Kementerian Riset, Teknologi, dan Pendidikan Tinggi yang telah membiaya pelaksanaan penelitian ini. Ucapan terimakasih juga kami sampaikan kepada Ketua Lembaga Penelitian 
dan Pengabdian kepada Masyarakat Universitas Udayana yang telah memfasilitasi urusan administrasi terkait dengan pelaksanaan penelitian ini. Kepada keluarga besar Puri Agung Bunutin dan pengurus Pura Penataran Agung Dalem Jawa Bunutin, kami mengucapkan terimakasih yang tak terhingga atas segala bantuan dan kerjasamanya sejak awal hingga berakhirnya penelitian ini.

\section{Daftar Pustaka}

Agger, Ben. 2003. Teori Sosial Kritis, Kritik, Penerapan dan Implikasinyya. (Nurhadi, penerjemah). Yogyakarta: Kreasi Wacana.

Ariana, I Nyoman. 2017. Penelusuran Wisata Damai Monumen Ground Zero Kuta, Bali. Denpasar: Pustaka larasan Bekerja sama dengan Fakultas Pariwisata Universitas Udaya.

Asmaul-husna.com. 2019. Sejarah dan Makna Idul Qurban. http://www. asmaul-husna.com/2015/08/sejarah-dan-makna-idul-adha-sejarah. html, diakses 7 Oktober 2019.

Bakar, Abu. 2016. Argumen Al-Qur'an tetang Eksklusivisme, Inklusivisme dan Pluralisme. Toleransi Media Ilmiah Komunikasi Umat Beragama, Volume 8 Nomor 1, 2016.

Blum, Lawrence A. 2001. “Antirasisme, Multikulturalisme, dan Komunitas Antar-Ras : Tiga Nilai yang Bersifat Mendidik Bagi Sebuah Masyarakat Multikultural". Larry May, Shari Collins-Chobanian, dan Kai Wong (ed.) : Etika Terapan I Sebuah Pendekatan Multikultural. Yogyakarta: PT Tiara Wacana Yogya.

Brahmana, Pertampilan Sembiring. 2003. Daliken Si Telu dan Solusi Masalah Sosial pada Masyatakat Karo: Kajian Sistem Pengendalian Sosial. USU Digital Library. epository.usu.ac.id., diakses 4 Oktober 2019.

Putra, Darma I Nyoman. 2017. “Puja Mandala Nusa Dua : Monumen Bhinneka Tunggal Ika Bali untuk Indonesia". Prosiding Seminar Nasional Kajian Mutakhir Bahasa, Sastra, dan Budaya Daerah untuk Membangun Kebhinekatunggalikaan Negara Kesatuan Republik Indonesia. Surakarta: Program Studi Sastra Daerah Fakultas Ilmu Budaya Universitas Sebelas Maret, Jumat-Sabtu, 25-26 Agustus 2017. 
Fadl, Khaled Abou El. 2006. Selamatkan Islam dari Muslim Puritan. Jakarta: Serambi.

Fay, B.1996. Contemporary Philosophy of Social Science: A Multicultural Approach. Oxford: Blackwell.

Griffin, Jill. 2003. Customer Loyalty. Jakarta: Erlangga.

Hasan, Ustad Ahmad. 2014. “Tiga Inti Pokok Makna dalam Berkurban Idul Adha". Mutiara Public Media Inspirasi dan Penyejuk Hati.

Hermawati, Rina; Caroline Paskarina; Nunung Runiawati. 2016. “Toleransi Antarumat Beragama di Kota Bandung". UMBARA : Indonesian Journal of Anthropology Volume 1 (2) Desember 2016.

Huntington, Samuel P. 2002. Benturan Antarperadaban dan masa Depan Politik Dunia. (M. Sadar Ismail, penerjemah). Yogyakarta: Penerbit Qalam.

Ismayanti. 210. Pengantar Pariwisata. Jakarta: Grasindo.

Jamaludin, Adon Nasrullah. 2018. “Konflik dan Integrasi Pendirian Rumah Ibadah di Kota Bekasi". Socio Politica. Volume 8 Nomor 2, Juli 2018.

Jary, D. dan J. Jary. 1991 'Multiculturalism', Dictionary of Sociology. New York: Harper. Hlm.319.

Kozak, M dan Rimmington, M. 2000. Tourist Satisfaction With Mallorca, Spain As An Offseason Holiday Destination, Journal Of Travel Research, Vol. 38, February, Pp. 260- 269.

Kymlicka, Will. 2002. Kewargaan Multikultural. Pengantar : F. Budi Hardiman. Jakarta: Penerbit PT Pustaka LP3ES Indonesia.

Lubis, M. Abduh. 2017. “Budaya dan Solidaritas Sosial dalam Kerukunan Umat Beragama di Tanah Karo". Jurnal Sosiologi Agama, Volume 11 No.2 Juli-Desember, 2017.

Madjid, Nurcholis. 2001. "Etika Beragama dari Perbedaan menuju Persamaan". Dalam : Pluralitas Agama Kerukunan dalam Keragaman". Editor : Nur Achmad. Jakarta: Penerbit Buku Kompas.

Miksic, John.1996. “Chronologi Timeline". Indonesian Heritage, Vol. I. Jakarta: Buku Antar Bangsa for Glorier International Inc. 
Hlm. 521-546 Daya Tarik Wisata Pura Langgar: Representasi Persaudaraan Hindu-Islam ...

Mursyid, Salma. 2016. "Konsep Toleransi (Al-Samahah) antarumat Beragama Perspektif Islam". Jurnal Aqlam Journal of Islam and Plurality. Volume 2, Nomor 1, Desember 2016.

Pujaastawa, Ida Bagus Gde. 2008. “Melacak Prinsip-prinsip Solidaritas Antaragama Menuju Tatanan Masyarakat Indonesia Multikultural". Artikel dalam Buku Kebudayaan dan Modal Budaya Bali dalam Teropong Lokal, Nasional, Global. Penerbit: Widya Dharma.

Pujaastawa, Ida Bagus Gde. 2009."Aktualisasi Nilai-nilai Budaya Bali dalam Menyikapi Keberagaman". Artikel dalam buku : Kampung Dunia : Potret Multikulturalisme Bali. Editor : Sri Rahayu Budiarti dan Muslimin AR Effendi. Jakarta: Departemen Kebudayaan dan Pariwisata.

Reken, I Wayan. 1979. Sejarah Perkembangan Islam di Bali Khususnya di Kabupaten Jembrana. Manuskrip Tidak Diterbitkan.

Satrya, Dewa Gde. 2014. Pariwisata Budaya untuk Perdamaian Dunia. Kontan 3 Januari 2014 halaman 2. Jakarta: Universitas Ciputra.

Sutika, I Ketut. 2012. Pakelem Kearifan Lokal Tangkal Bencana. bali. antaranews.com, diakses 8 Oktober 2019.

Swasono, Sri Edi.2003. Koperasi Sebagai Mata Kuliah di Universitas : Dapatkah Koperasi Menjadi Pilar Orde Ekonomi Indonesia?. Makalah Seminar Bulanan ke-10 Pustep UGM, dengan tema "Ilmu Koperasi Bagi Indonesia". Yogyakarta, 4 November 2003.

Tilaar, H.A.R. 2004. Multikulturalisme Tantangan-tantangan Global Masa Depan dalam Transformasi Pendidikan Nasional. Jakarta: PT Gramedia Widiasarana Indonesia.

Undang-Undang Republik Indonesia Nomor 9 Tahun 1990 tentang Kepariwisataan

Unesco. 2011. Berinvestasi dalam Keanekaragaman Budaya dan Dialog Antarbudaya. Edisi Bahasa Indonesia. Penerjemah: Dwi A. Indrasari. Editorial: Wieske O. Sapardan dan Anasthasia R. Herna.

Watson, C.W. 2000. Multiculturalism. Buckingham-Philadelphia: Open University Press.

Wiana, Ketut. 2004. Mengapa Bali disebut Bali? Surabaya: Paramita. 
Widyarshana, Ida I Dewa Oka. 2008. Sekelumit Babad Wong Agung Willis. Bangli: Pasemetonan Ageng Dalem Blambangan Puri Agung Bunutin, Bangli-Bali. Naskah Tidak Diterbitkan. 